ЦИФРОВІЗАЦІЯ ПСИХОЛОГІЧНОЇ ДОПОМОГИ ЗА ГІБРИДНИХ ВИКЛИКІВ

\title{
DIGITALIZATION OF PSYCHOLOGICAL ASSISTANCE AT HYBRID CHALLENGES
}

\begin{abstract}
Цифрові технології проникли у більшу частку сорер життя особистості, що має свою амбівалентність позитивного і негативного впливів. у статті піднімається проблема цифрровізації психологічної допомоги, окреслено ї̈ можливості і наведено виклики, з якими стискається людина у цифрову епоху. У час інформаційно-технічного прогресу особистість фрункціонує у полі гібридних викликів, що характеризуються поміссю реальних і віртуальних небезпек, які невпинно модифрікуються у більш складні форми та прогресують щодо впливовості на психіку людини, тому метою дослідження стало обгрунтування і розроблення програмного засобу для оцінки психоемоційних станів особистості за гібридних викликів сучасності. Представлений програмний засіб «РДЦ-1» створювався для побудови комплексної психологічної діагностики, що спрямована на виявлення гострого й хронічного стресу, соматичних проявів, індивідуально-психологічних характеристик, реакціі на труднощі, з якими стикається людина, та встановлення шляхів вирішення актуальних проблем. Дослідження проводилося на базі державного закладу «Науково-практичний медичний реабілітаційно-діагностичний чентр МОЗ України». У дослідженні прийняло участь 244 особи у віці від 21 до 75 років. Середній вік - 44,5 $\pm 11,3$ року. За результатами експериментальних даних у 31,1\% виявлено погіршення емоційного стану, у 9\% встановлено незадовільний емочійний стан. Погіршення фрізичного стану - у 29,1\%, незадовільний фрізичний стан -у 5,3\%, зниження працездатності - у 18,9\%, наявність окремих ознак посттравматичного стресового розладу (ПТСР) - у 31,9\% респондентів, а власне ПТСР (за результатами психологічних характеристик) - у 13,2\%. Цияровізація психологічної допомоги дає змогу прискорити і підвищити якість психодіагностичного процесу, допомогти знайти першопричину, чітко спланувати корекційну роботу, виявити групи ризику.
\end{abstract}

Ключові слова: особистість, суспільство, психодіагностика, інфрормаційні технології, програмний засіб, емоції, ПТСР.

Digital technologies have penetrated most areas of a person's life, which has its ambivalence of positive and negative influences. The human acts today in a field of hybrid challenges, characterized by a mixture of both real and virtual dangers, which are constantly modified into more complex forms and progress in terms of impact on the human psyche. The purpose of the article is to substantiate and develop an app for assessing the psycho-emotional states of the individual in modern hybrid challenges. The presented app "RDC-1" was created to build a comprehensive psychological diagnosis aimed to identify acute and chronic stress, somatic appearances, individual psychological characteristics, reactions to difficulties the person is faced with, and establishing ways to solve modern issues. The study was conducted on the basis of the state institution "Scientific and Practical Medical Rehabilitation and Diagnostic Center of the Ministry of Health of Ukraine". The study involved 244 people aged 21 to 75 years. The average age is $44.5 \pm 11.3$ years. According to the results of experimental data, $31.1 \%$ of respondents showed deterioration of emotional state, 9\% have unsatisfactory emotional state. Deterioration of physical condition is $29.1 \%$, unsatisfactory physical condition is 5.3\%, decreased ability to work established for $18.9 \%$, the availability of some signs of post-traumatic stress disorder (PTSD) have $31.9 \%$ of respondents and PTSD (according to psychological characteristics) have $13.2 \%$ of respondents. Digitization of psychological help allows to speed up and improve the quality of the psychodiagnostic process, help to find the root cause, clearly plan corrective work, as well as to identify risk groups. The results can be used to develop medical, psychological and rehabilitation measures for people with PTSD.

Key words: personality, society, psychodiagnostics, information technologies, software, emotions, PTSD.
XXI ст. характеризується інтенсивним розвитком цифрових технологій. Вони стрімко входять у різні галузі і сфери життя людини з метою збільшення комфорту і розширення її можливостей. Але поряд із технічним прогресом існує достатньо широкий колорит викликів сьогодення, поєднання яких набирає гібридного окрасу, що примножує негативний вплив на людську психіку, знижуючи ресурсний потенціал особистості і посилюючи розвиток психічної патології серед населення як однієї країни, так і всього світу в цілому.

Сьогодні цифровізація суттєво охопила простори економічної розбудови країни та формування національної безпеки, сектор промисловості й фінансів, соціальну діяльність, систему охорони здоров'я та освіти.
Зокрема, цифрові технології представлено у діагностиці різних проявів фізичного і психічного станів особистості [1-4], а отже, цифрові досягнення повинні бути більш активно впроваджені у модернізацію психологічної допомоги населенню у час соціально-економічних негараздів та гібридної війни, що спрямована проти здорової конкурентоспроможної особистості та міцної нації.

За даними Всесвітньої організації охорони здоров'я, психічні та поведінкові розлади проявляються у понад 25\% усіх людей у певні періоди їхнього життя й є дуже поширеними в усьому світі. Виняткове значення серед психічних розладів займають тривожні і стресові розлади, пов'язані з такими надзвичайними подіями, як війни, терористичні акти, 
пандемії, великі техногенні аварії та природні катаклізми [5-7].

Наукові дослідження показують, що за тривожних розладів діагностуються наявність постійної внутрішньої напруги, порушення концентрації і розподілу уваги на дійсні загрози [8]. Отже, відбувається зниження процесів адаптації та реагування на події, що відбуваються на тлі виснаження ресурсів організму, й у подальшому це може призвести до розвитку психосоматичних і глибших форм психічних хвороб.

Мета роботи - обґрунтувати та розробити програмний засіб для оцінки психоемоційних станів особистості за гібридних викликів сучасності.

Несприятливі тенденції соціально-політичних подій останніх років, серед яких - військовий конфлікт, соціально-економічна нестабільність, інформаційна війна, відображаються на самопочутті населення, особливо негативний тиск підвищується через гібридність цих викликів, з якими стикається людина у сучасних умовах свого буття.

Само поняття «гібрид» прийшло з галузей агрономії та селекціонерства, що означає тваринний або рослинний організм, виведений за допомогою гібридизації (схрещування). Друге тлумачення - це помісь одного з іншим [9]. І це поняття все частіше зустрічається у соціальній і політичній сферах суспільства у вигляді поняття «гібридна війна». Останнє характеризується розпалюванням конфлікту, прогресуванням ворожих дій із використанням різноманітних методів, технік і форм впливу. При цьому перевага надається не класичному веденню бойових дій та використанню реальної зброї, а першочерговим є створення інформаційного тиску і збільшення масштабів кібервійни.

Таким чином, гібридність викликів представляється тим, що поряд із реальними складнощами, що призводять до зниження рівня життя (збільшення безробіття, зменшення виробництва, підвищення тарифів на комунальні послуги, продукти харчування, соціальне обслуговування та ін.), існує «інформаційна підтримка» цих явищ, примножуючи у рази дійсний стан справ усередині суспільства та країни взагалі. За таких обставин відбувається підміна понять, що вносять суттєвий дисонанс у розуміння істинної ситуації теперішнього часу. Для подібного розробляються цілі спеціальні концепції для проведення подібних складних операцій, що супроводжуються поширенням фейкових подій, надшвидкою і радикально протилежною зміною новин, а також чітко спланованим посиленням емоційного забарвлення.

Отже, у час інформаційно-технічного прогресу цифри особистість функціонує у полі гібридних викликів, що характеризуються поміссю реальних і віртуальних небезпек, які невпинно модифікуються у більш складні форми та прогресують щодо впливовості на психіку людини. Подібні речі значно збільшили частину населення 3 психологічними проблеми, що потребує кваліфікованої спеціалізованої допомоги [10]. У зв'язку із цим актуальною стала проблема своєчасного виявлення зазначеної категорії людей. Дана потреба детального вивчення психологічного стану населення України позначила необхідність створення програмного засобу для охоплення більшого числа людей і скорочення часу для обробки діагностичного матеріалу.

у рамках виконання науково-дослідної роботи за замовленням МО3 України «Розроблення системи реабілітації медико-психологічного спрямування особам в умовах інформаційно-психологічної війни» (20202022 рр., № держреєстрації - 0120U101304) та за результатами минулих досліджень [11] розроблено програмний засіб «РДЦ-1». Дана розробка створювалася з метою виявлення актуального психоемоційного стану та можливості ведення моніторингу. Психологічна діагностика є комплексною та спрямована на виявлення гострого й хронічного стресу, соматичних проявів, індивідуально-психологічних характеристик, реакції на виникаючі труднощі та шляхи вирішення актуальних проблем.

Для розроблення програмного засобу були впроваджені авторська анкета та чотири надійні валидизовані психологічні методики: авторська анкета «Оцінка особистості, яка пережила події, пов'язані з бойовими подіями»; тест 1 - МШПР (Міссісіпська шкала посттравматичного стресового розладу для діагностики посттравматичного стресового розладу); тест 2 - SCL-90-R (методика SCL-90-R - для дослідження актуального психоемоційного стану та визначення невідкладних психічних проблем); тест 3 - ОСР (Опитувальник суїцидального ризику в модифікації Т.М. Разуваєва - виявлення рівня сформованості суїцидальних намірів та попередження серйозних спроб самогубства); тест 4 - ОСП (Опитувальник Лазаруса - для визначення копінг-механізмів, способів подолання труднощів у різних сферах психічної діяльності, коппінг-стратегій).

Дослідження проводилося на базі державного закладу «Науково-практичний медичний реабілітаційно-діагностичний центр МОЗ України». У дослідженні взяли участь 244 особи у віці від 21 до 75 років. Середній вік - 44,5 \pm 11,3 року. У співвідношенні за статевою ознакою більше переважали жінки (рис. 1).

За результатами анкетування встановлено, що свідками військових дій уважають себе 63,9\% респондентів (156 осіб), морально постраждали - 67\% (168 осіб), а матеріально - 


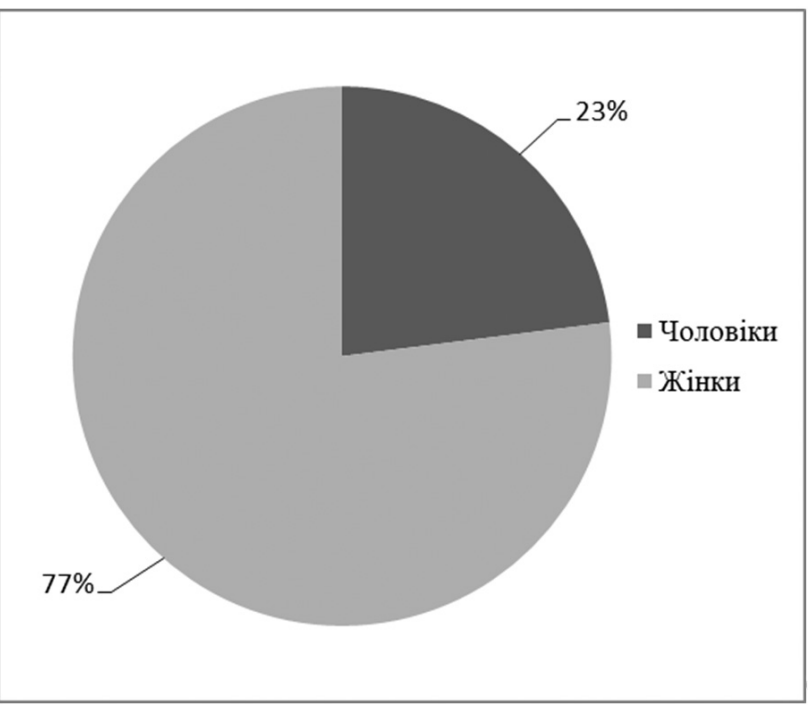

Рис. 1. Співвідношення вибірки за статевою ознакою

33\% (76 осіб). Під час анкетування респондентам надавалася можливість відзначити, які емоції у них переважали останнім часом. Таким чином, було засвідчено, що такими емоціями стали тривога (150 осіб), безпорадність (56 осіб), роздратування (79 осіб), страх (45 осіб), відчай (44 особи), смуток - (40 осіб), байдужість - (13 осіб). Задля наочного розуміння і відсоткового співвідношення результати представлено на рис. 2.

У $31,1 \%$ (76 осіб) виявлено погіршення емоційного стану, у 9\% (22 особи) встановлено незадовільний емоційний стан. Погіршення фізичного стану - 29,1\% (71 особа), незадовільний фізичний стан - 5,3\% (13 осіб), зниження працездатності - 18,9\% (46 осіб).
Оцінка поточного психічного стану показала наявність окремих ознак посттравматичного стресового розладу (ПТСР) у $31,9 \%$ респондентів (78 осіб), а власне ПТСР (за результатами психологічних характеристик) - у 13,2\% (33 особи).

Під час вивчення окремих симптомів психічної та соматичної патології (табл. 1) виявлено соматизацію (81 особа), ознаки депресії (92 особа) та тривожність (85 осіб).

\section{Прояви соматичної і психічної патології серед респондентів}

\begin{tabular}{|c|c|}
\hline Категорії & $\begin{array}{c}\text { Відсоткове } \\
\text { співвідношення }\end{array}$ \\
\hline Ознаки депресії & $37,7 \%$ \\
\hline Тривожність & $34,3 \%$ \\
\hline Соматизація & $33,2 \%$ \\
\hline
\end{tabular}

Виявлені респонденти були направлені на консультацію психіатра для донозологічної діагностики (за наявності окремих ознак ПТСР) і формування клінічного діагнозу (клієнти з ПТСР).

Під час вивчення рівня сформованості суїцидальних намірів у 28,7\% респондентів спостерігалася негативна концепція навколишнього світу (соціальний песимізм). У цієї групи респондентів переважало вороже прийняття світу, яке не відповідає уявленням про сприятливі або задовільні для людини відносин з оточуючими.

Злам культурних бар'єрів як пошук культурних цінностей і нормативів, що виправдовують суїцидальну поведінку або частково вважають її привабливою, встановлено у 17,6\% клієнтів. Даний показник діагностує культ самогубства, що вимагає більш детального вивчення

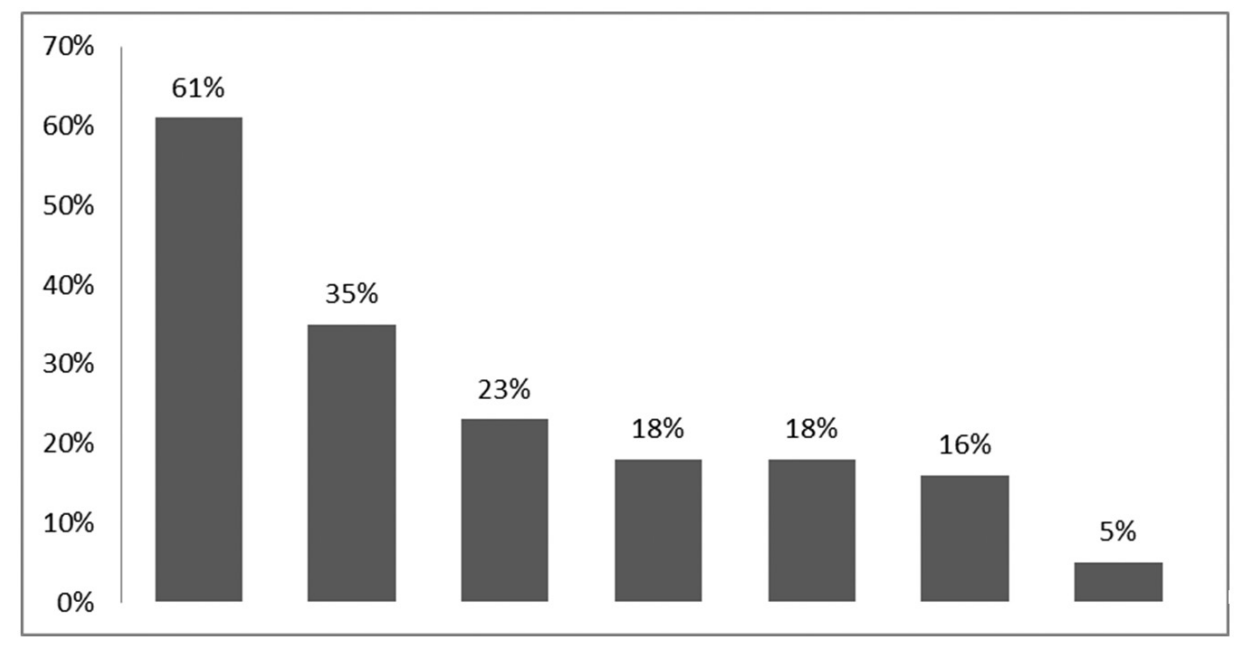

Рис. 2. Самооцінка переважних емоцій серед респондентів

Примітка: 1 - тривога; 2 - роздратування; 3 - безпорадність; 4 - страх; 5 - відчай; 6 - смуток; 7 - байдужість 
особистості з метою виявлення патологічних установок і аутоагресії з обов'язковою консультацією лікаря-психіатра. Тільки у 20,5\% респондентів чітко переважало глибоке розуміння почуття відповідальності за близьких і почуття обов'язку жити.

Не менш важливим і актуальним стало вивчення копінг-стратегій кожного респондента як способу протистояння гібридним викликам і можливості подолання труднощів у різних сферах психічної діяльності. Задля успішного та комфортного існування та чи інша стратегія повинна мати адаптивний рівень прояву. Чим яскравіше виражений копінг, тим сильніше спостерігається дезадаптація людини. За результатами дослідження найбільш вираженими та напруженими копінгами стали такі види: «Планування рішень проблеми» - 61,1\% (149 осіб), «Прийняття відповідальності» - 47,5\% (116 осіб), «Соціальна підтримка» - 45,5\% (111 осіб). Існує пряма кореляція між цими трьома позиціями. Під час розрахунків коефіцієнта автокореляції (rt, $\mathrm{t}-1=1 \rightarrow 1)$, згідно зі шкалою Чеддока $0.9<\mathrm{rt}$, $\mathrm{t}-1<1$, це дуже високий і прямий зв'язок. Це характеризується тим, що респонденти цілеспрямовано аналізують ситуації й опрацьовують можливі варіанти поведінки і власні дії з урахуванням об'єктивних умов, минулого досвіду і наявних ресурсів, використовують можливість застосування зовнішніх ресурсів для вирішення проблемної ситуації, зокрема відбувається пошук інформаційної, емоційної і дієвої підтримки від оточуючих, але при цьому простежується ймовірність надмірної раціональності, недостатньої власної емоційності, інтуїтивності і спонтанності в поведінці. Висока відповідальність формує надмірну пильність у прийнятті рішень, призводить до невиправданої самокритики, переживання почуття провини і незадоволеності собою. Зазначені особливості є чинниками ризику розвитку депресивних станів.

Високі показники копінг-стратегії «Самоконтроль», що встановлені у 41,6\% респондентів (104 особи), говорить про спроби подолання негативних переживань, пов'язаних з актуальними проблемами, відбувається за рахунок цілеспрямованого придушення і стримування емоцій, мінімізації їхнього впливу на оцінку ситуації і вибір стратегії поведінки, високий контроль поведінки, прагнення до самовладання. Тим самим виникають труднощі вираження переживань, потреб і спонукань у зв'язку з проблемною ситуацією, і переважає надконтроль поведінки.

Високий рівень «Конфронтації» (26,2\% 64 респонденти) робить спроби вирішення проблеми за рахунок не завжди цілеспрямованої поведінкової активності, здійснення конкретних дій, спрямованих або на зміну ситуації, або на реагування негативних емоцій у зв'язку з появою труднощів. За вираженої переваги цієї стратегії спостерігаються імпульсивність у поведінці (іноді з елементами ворожості і конфліктності), ворожість, перешкоди у плануванні дій, прогнозуванні їхнього результату, корекції стратегії поведінки, невиправдана завзятість. Своєю чергою, «Уникнення» (19,7\% - 48 респондентів) і «Дистанціювання» (25\% - 61 респондент), припускають спроби подолання особистістю негативних переживань у зв'язку з труднощами за рахунок реагування за типом ухилення: заперечення проблеми, фантазування, невиправдані очікування, відволікання. I, як наслідок, неможливість розв'язання проблеми, ймовірність накопичення труднощів, короткостроковий ефект зроблених дій зі зниження емоційного дискомфорту.

Таким чином, за цифровізацією психологічної допомоги стоїть успішна розбудова цього напряму в майбутньому, оскільки цифрові технології надають можливість прискорити і підвищити якість психодіагностичного процесу, допомогти знайти першопричину, чітко спланувати корекційну роботу, виявити групи ризику.

Через низький супротив стресу, відсутність правильної копінгової поведінки суспільні події й особові негаразди стають травматичними для особистості, психічні реакції якої можуть бути різного характеру, що залежать від інтенсивності і тривалості впливу негативних чинників.

Цифрова оптимізація масових досліджень виконує загальносоціальну й окрему медико-психологічну функції, акцентує увагу фахівців медичної ланки на психологічних проблемах пацієнтів, а це сприяє формуванню партнерських відносин між лікарем, пацієнтом та психологом. Такий підхід - запорука попередження розвитку психічної патології, профілактика проявів агресивної поведінки та інших протиправних дій серед населення.

Цифровізація психологічної ланки у її поєднанні з медичною є основою для розроблення організаційно-правових принципів і положень формування медико-психологічної, соціальної підтримки, розроблення механізмів, форм і методів психологічного захисту особистості у час гібридних викликів, а також прогнозування їхніх наслідків у сучасних умовах інформаційного середовища.

\section{ЛIТЕРАТУРА:}

1. Selivanova K.G., Avrunin O.G., Zlepko S.M., Zyska T. Kalimoldayev M. Virtual training system for tremor prevention. Information Technology in Medical Diagnostics II: Proceedings of the International Scientific Internet Conference "Computer Graphics and Image Processing" and the XLVIII th International Scientific and Practical Conference "Application of Lasers in Medicine and Biology", Editor by Wojcik, Pavlov, Kalmodaev. 2018. ISBN 978-0-367-17769-0.2018. P. 9-14. 
2. Avrunin O.G., Tymkovych M.Y., Moskovko S.P. Using a priori data for segmentation anatomical structures of the brain. Przeglacd Elektrotechniczny, 2017. №. 3. P. 102-105. DOI: 10.15199/48.2017.05.20.

3. Костін Д.О., Кабанцева А.В. Розробка пристрою 3 біологічно-зворотним зв'язком для оцінки актуального стану здоров'я людини. 25-й Міжнародний молодіжний фоорум «Радіоелектроніка та молодь у XXI столітmі» : зб. матеріалів фроруму. Т. 1. Харків : ХНУРE, 2021. С. 149-150.

4. Гуменюк В.В., Антонов В.Г., Кабанцева А.В. Инфрормационные технологии в медико-психологическом контроле. Медицинский и психологический контроль состояния человека : сборник научных работ / под ред. профр. О.А. Панченко. ИПП «Контраст», 2016 C. 20-28.

5. Sonpaveerawong J., Limmun W., Chuwichian N. Prevalence of Psychological Distress and Mental Health Problems among the Survivors in the Flash Floods and Landslide in Southern Thailand, Walailak J Sci \& Tech, 2017. №. 16. P. 255-264.

6. Wichaidit S., Songwathana P., Balthip K., and Woods M. Healing Strategies among Thai Buddhist
Widows after Sudden of Loss of Spouse in Terrorist Attacks, Walailak J Sci \& Tech. 2018. №. 16. P. 243-254.

7. Neria Y., Nandi A., Galea S. Post-traumatic stress disorder following disasters: a systematic review. 2008. № 38. P. 467-480. DOI: https://doi.org/10.1017/ S0033291707001353.

8. Bar-Haim Y., Lamy D., Pergamin L., BakermansKranenburg M., van IJzendoorn M.H. 2007. Threatrelated attentional bias in anxious and nonanxious individuals: a meta-analytic study. Psychol. Bull. 133:1-24. DOI: 10.1037/0033-2909.133.1.1.

9. Академічний тлумачний словник : вебсайт. URL: http://sum.in.ua/s/ghibryd (дата звернення: 21.05.2021)

10. Кабанцева А.В., Костін Д.О., Гуменюк В.В. Людина в інформаційній загрозі. The 9th International scientific and practical conference "Dynamics of the development of world science" (May 13-15, 2020) Perfect Publishing, Vancouver, Canada. 2020. C. 550-559.

11. Кабанцева А.В., Панченко О.А. Паніка як психологічний фрактор інформаційної небезпеки особистості. Психологія і особистість. 2020. Вип. 2(18). C. 9-22. 